\title{
Assemblage of medium and large size mammals in an urban Semideciduous Seasonal Forest fragment in Cerrado biome
}

\author{
Paulo Vitor dos Santos Bernardo ${ }^{1,3}$ \& Fabiano Rodrigues de Melo ${ }^{1,2}$ \\ ${ }^{1}$ Programa de Pós-graduação em Ecologia e Evolução, Universidade Federal de Goiás -UFG, \\ CEP 74001-970, Goiânia, GO. www.ecoevol.ufg.br \\ ${ }^{2}$ Curso de Ciências Biológicas, Universidade Federal de Goiás - UFG, Br 364, Km 192, \\ Parque Industrial, CEP 75801-615, Jatai, GO \\ ${ }^{3}$ Corresponding author: Paulo Vitor dos Santos Bernardo, e-mail: pauloviti@gmail.com
}

BERNARDO, P.V.S. \& MELO, F.R. Assemblage of medium and large size mammals in an urban Semideciduous Seasonal Forest fragment in Cerrado biome. Biota Neotrop. 13(2): http://www.biotaneotropica. org.br/v13n2/en/abstract?article+bn02813022013

\begin{abstract}
Nowadays, the processes of deforestation and loss of habitats represent a major threat to many species of mammals. These processes cause changes in natural landscapes by decreasing area, connectivity, and fragment size, and increasing edge effects and number of fragments. Understanding which and how many species persist in disturbed fragments may indicate the species' minimum requirements and might contribute to their conservation. Here we show how the mammalian fauna of medium and large size (higher than $1 \mathrm{~kg}$ ) are structured in a semideciduous seasonal forest fragment of 36.5 ha in the urban area of Jataí, Goiás. We performed the sampling with 30 sand track plots $(1 \times 1 \mathrm{~m})$. We analyzed the relative record frequency and built a collector's curve to demonstrate the sampling effort. With a total effort of 600 track plots $\times$ days, we recorded twelve species of mammals with our tracks sampling method, from which only the wild mammals were included in the analyzes (11 species). The estimated species richness reached 13 species (SD (Standard Deviation) $= \pm 1$, CI (Confidence Interval $)= \pm 2(11-15$ species $)$. The species with the highest relative record frequency was Didelphis albiventris and the species with the lowest was Tamandua tetradactyla. The fragment size must be a limiting factor to the richness and to the occurrence of species, as it may not be sufficient to allow the persistence of a population or an individual. Disturbances that originated from houses, like domestic animals and movement of people, also contributed to the removal and extinction of species. To conserve the species in the fragment, we suggest the prevention of entrance of people and of domestic animals. We also recommend increased connectivity of the fragment with the landscape external to the urban area in order to allow the movement of the currently present species.
\end{abstract}

Keywords: Goiás Southwest, habitat fragmentation, habitat loss, mammalian fauna, urban ecology.

BERNARDO, P.V.S. \& MELO, F.R. Composição e caracterização dos mamíferos de médio e grande porte em um fragmento urbano de Floresta Estacional Semidecidual no bioma Cerrado. Biota Neotrop. (13)2: http://www.biotaneotropica.org.br/v13n2/pt/abstract?article+bn02813022013

Resumo: Atualmente, os processos de perda e fragmentação de habitats representam uma das maiores ameaças às espécies de mamíferos, provocando mudanças nas paisagens diminuindo a área natural, a conectividade e o tamanho dos fragmentos e aumentando o número dos fragmentos e o efeito de borda. Entender quais e quantas espécies habitam fragmentos perturbados pode indicar seus requerimentos mínimos contribuindo para sua conservação. Neste trabalho é mostrado como está estruturada a mastofauna de médio e grande porte $(>1 \mathrm{~kg}) \mathrm{em}$ um fragmento de Floresta Estacional Semidecidual de 36,5 ha na área urbana do município de Jataí, Goiás. A coleta foi realizada com o uso de 30 parcelas de areia $(1 \times 1 \mathrm{~m})$, foi também analisada a frequência de registro e construída uma curva do coletor para demonstrar o esforço de coleta. Com um esforço total de 600 parcelas/dias foram registradas doze espécies de mamíferos, mas somente não domésticas foram inclusas nas análises (onze espécies). A riqueza estimada foi de 13 espécies (DP (Desvio Padrão) $= \pm 1$, IC (Intervalo de Confiança) \pm 2 (11- 15 espécies). A espécie com a maior frequência relativa de registros foi Didelphis albiventris e a com menor frequência relativa foi Tamandua tetradactyla. O tamanho do fragmento deve ser um limitante para a riqueza e permanência das espécies, pois pode não ser suficiente para a persistência de uma população ou mesmo de um individuo. Perturbações advindas das moradias como animais domésticos e o trânsito de pessoas também devem contribuir para o afastamento e extinção das espécies. Para conservação das espécies no fragmento, sugerimos a proibição da entrada de pessoas e animais domésticos, bem como aumentar a conectividade do fragmento com a paisagem exterior à área urbana, a fim de permitir a movimentação das espécies presentes.

Palavras-chave: Sudoeste goiano, fragmentação de habitats, perda de habitat, mastofauna, ecologia urbana. 


\section{Introduction}

Nowadays, many anthropogenic activities promote fragmentation and habitat loss in natural landscapes, and both of these factors have been responsible for several losses to global biodiversity (Tabarelli \& Gascon 2005, Gibson et al. 2011). In Brazil, the Cerrado Biome is highly fragmented (Myers et al. 2000, Carvalho et al. 2009) due to its use for agriculture, cattle raising, and charcoal production (Miziara \& Ferreira 2008). Especially in Brazil, fragmentation has become a major challenge to the conservation of mammals (Costa et al. 2005) because it modifies the landscape, decreases the extension of the original habitat, and increases the creation and number of fragments. It also makes these fragments smaller and more isolated (Fahrig 2003).

The remaining Cerrado comprises about 20\% (Mittermeier et al. 2005 ) of its original extension (about $2.000 .000 \mathrm{~km}^{2}$ ) (Ratter et al. 1997), being one of the 35 most threatened areas of the world and having habitat loss and fragmentation of habitats as main threats (Myers et al. 2000, Mittermeier et al. 2005). The fragmentation processes have also caused the formation of vegetation fragments in urban areas in many places of the world (e.g. Crooks 2002, Fernández-Juricic 2002, Lacerda et al. 2009). The impacts of habitat fragmentation limit the presence of various species in the fragment because they restrict the area of the fragment (Chiarello 1999, Michalski \& Peres 2007). They also cause edge effects (Fahrig 2003) in the interaction between the fragment and the matrix (Murcia 1995, Stevens \& Husband 1998) and decrease landscape connectivity (Fahrig \& Merriam 1994, Sampaio et al. 2010). Aside from these factors, there are also factors present related to the proximity of households and urban centers. Edge effects are present especially in urban fragments such as invasion of exotic and domestic species (Crooks \& Soulé 1999, Crooks 2002, Lacerda et al. 2009) and the existence of adverse effects to the fauna arising from human contact. Adverse effects include waste disposal, hunting increase, and transit of people (Chiarello 1999, Peres 2001, Michalski \& Peres 2005).

The responses of the species to effects of habitat fragmentation are diverse. The species may decline dramatically and disappear, remain stable or increase in fragments (Crooks 2002, Laurance 2008). This process is related to the increase of human population density, road networks, pollution, and conversion of areas to agriculture and cattle farming (Costa et al. 2005). Due to these factors, the habitat loss and fragmentation process have been leading to the inclusion of many mammal species on the red list of threatened species of Brazil (Costa et al. 2005, Machado et al. 2008). In this scenario the fragments are important to conserve despite their size or location, because although they are small, they may have conservation value in increasing connectivity (e.g. Crooks 2002, Lacerda et al. 2009, Sampaio et al. 2010).

Identifying which species are present in remnants of native vegetation might reveal their levels of environmental requirements, assisting in the implementation of management strategies. For this purpose, inventorying the fauna of an ecosystem is the first step for its conservation. However, data in local and regional scales of mammals are still scarce. It would be impossible to develop any conservation plan without a minimum knowledge about the organisms that occur in a given site or how many species can be found there (Santos, 2006).

In this work, we show how the mammalian assemblage of medium and large size (weighing more than $1 \mathrm{~kg}$ ), is structured in an urban fragment of semideciduous seasonal forest.

\section{Methods}

\section{Study area}

The work was conducted in a fragment of semideciduous seasonal forest of $36.5 \mathrm{ha}\left(17^{\circ} 52^{\prime} 53^{\prime}\right.$ ' $\mathrm{S}$ and $51^{\circ} 42$ ' $52^{\prime}$ ' W, $708 \mathrm{~m}$ of elevation from sea level), located in the urban area of the municipality of
Jataí, state of Goiás, in Brazil (Figure 1). This fragment contains only one small link to the external area of the city (a soybean field) with no connection to other fragments. The landscape of this region is dominated by monocultures (Carvalho et al. 2009), mainly of soybean, corn and sugarcane, with the presence of pastures and native vegetation fragments. This region is located in the domains of the Cerrado biome, which presents a seasonal climate with two remarkable periods: a rainy season that lasts from October to March and a dry season, lasting from April to September (Ratter et al. 1997, Klink \& Machado 2005). The mean annual temperatures in Jataí is $22^{\circ}$ and the mean annual precipitation ranges from 1650 to $1800 \mathrm{~mm}$ (Rocha et al. 2012).

\section{Data sampling}

The sampling was conducted in three transects (each 200m long) crossing the forest perpendicularly to a stream that passes through the fragment. The three transects were respectively designed as A, $\mathrm{B}$ and $\mathrm{C}$, where $\mathrm{A}$ and $\mathrm{B}$ were $25 \mathrm{~m}$ away from each other and, due to the presence of the stream (Açude Stream), transects B and C were $50 \mathrm{~m}$ away from each other. For each transect, 10 track plots with dimensions of $1 \mathrm{~m} \times 1 \mathrm{~m}$ containing fine sand were placed and listed, being twenty meters distant from each other. We went on field excursions for sampling on two consecutive days in most months, but in the first month we did the sampling on four consecutive days. We conducted nine monthly samplings, from August 2008 to May 2009. During the excursions, each track plot was baited with a piece of banana and, after 24 hours, was checked for tracks. When tracks were present, we made a photographic record and identified the footprints using the field guides of Becker \& Dalponte (1991) and Borges \& Tomás (2004).

\section{Data analysis}

We calculated the frequency of species (number of records/track plots $\times$ days of sampling) and using the software EstimateS (Colwell 2000) version 7.5, we estimated the species richness through the Jackknife 1 estimator (Heltshe \& Forrester 1983) to confirm the validation of the sampling effort. If domestic species were recorded, they were not included in the richness analysis.

\section{Results}

With a total effort of 600 track plots, we recorded twelve taxa of mammals (Table 1), and the estimated richness was 13 species $(\mathrm{SD}= \pm 1, \mathrm{IC}= \pm 10.5$ to 14.6 ) (Figure 2). We recorded the domestic species Canis lupus familiaris (Linnaeus, 1758) (pet dog) and a species of Felidae that we were unable to confirm, although it was a small cat that could be identified as a domestic or wild cat. However, because there was doubt, this species was included in the richness analysis. The sampling effort of 600 track plots was sufficient to register all or most of the medium and large sized mammals of the fragment (that were eligible to be recorded by the used methodology).

The most frequently recorded medium and large sized species in the fragment were Didelphis albiventris (relative frequency of 0.200), Dasypus novemcinctus (0.065) and Dasyprocta azarae (0.058). While the least frequently recorded species were Coendou prehensilis (0.003) and Tamandua tetradactyla (0.002). The domestic species, Canis lupus familiaris, was also rarely recorded (0.010 of the track plots).

\section{Discussion}

The estimated richness of 13 species was relatively high when the size of the fragment is considered (36.5 ha), but many common species of the region were absent. An isolated fragment like the one 


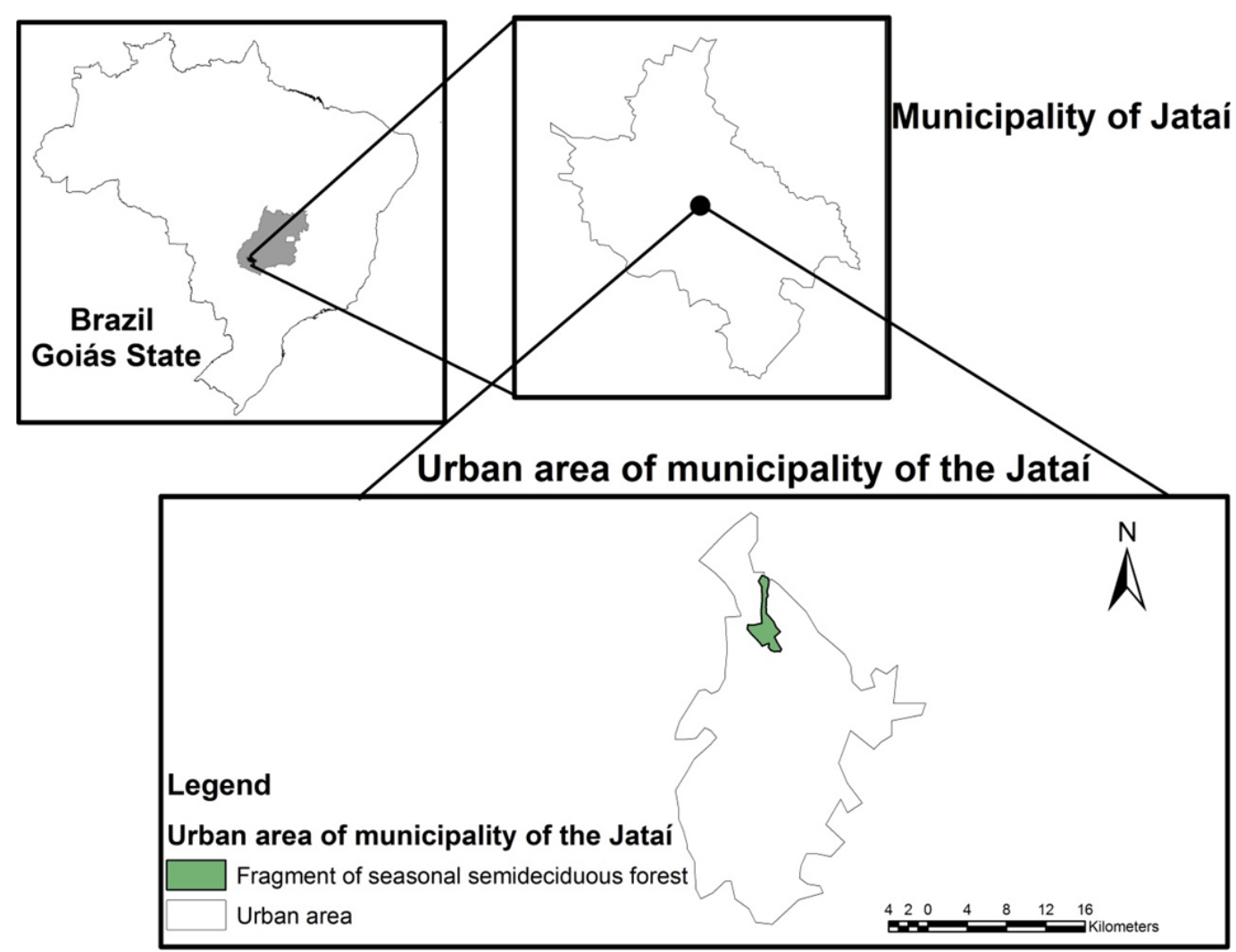

Figure 1. Localization of the municipality of Jataí in the state of Goiás, where the studied fragment of seasonal semideciduous forest is located and where the sampling method of sand track plots was conducted to sample medium and large sized mammals between August 2008 and May 2009.

Table 1. List and relative frequencies of the species recorded by the methodology of sand track plots in an urban forest fragment in Jataí, Goiás. The frequency refers to 600 sampled track plots, the values are sorted in descending order.

\begin{tabular}{llc}
\hline \multicolumn{1}{c}{ Species } & \multicolumn{1}{c}{ Common names } & Relative record frequency \\
\hline Didelphis albiventris Lund, 1840 & opossum & 0.200 \\
Dasypus novemcinctus Linnaeus, 1758 & nine-banded armadillo & 0.065 \\
Dasyprocta azarae Lichtenstein, 1823 & agouti & 0.058 \\
Eira barbara (Linnaeus, 1758) & tayra & 0.050 \\
Myrmecohaga tridactyla Linnaeus, 1758 & giant anteater & 0.033 \\
Procyon cancrivorus (G. Cuvier, 1798) & crab-eating raccoon & 0.025 \\
Nasua nasua (Linnaeus, 1766) & ring-tailed coati & 0.015 \\
Cuniculus paca (Linnaeus, 1766) & lowland paca & 0.013 \\
Felidae sp. & cat & 0.013 \\
Canis lupus familiaris (Linnaeus, 1758) & pet dog & 0.010 \\
Coendou prehensilis (Linnaeus, 1758) & brazilian porcupine & 0.003 \\
Tamandua tetradactyla (Linnaeus, 1758) & lesser anteater & 0.002 \\
\hline
\end{tabular}

of this study will hardly maintain a rich fauna of medium and large sized mammals, because small fragments are certainly not adequate to maintain a population or even an individual of the species (Fahrig \& Merriam 1994). This expectation is confirmed by our results, where the majority of the recorded species are midsized. The largest mammal recorded was Myrmecophaga tridactyla (tamanduábandeira) with average $30.5 \mathrm{~kg}$ (Emmons \& Feer 1997). Species like Tapirus terrestris (Linnaeus, 1758) (tapir), Mazama americana (Erxlesben, 1777) (red brocket), Tayassu pecari (Link, 1795) (white-lipped peccary) e Pecari tajacu (Linnaeus, 1758) (collared peccary) are common to the region (personal observation), but they do not use the fragment, where they must have been extinct due to absence of conditions of utilization, like size and edge effect. The presence of mammals is usually limited by the area size (Chiarello 1999, Michalski \& Peres 2007), which is a problem common in urban fragments, because in general the fragments are small. Beyond the area limitation of the fragment, the edge effect may also cause negative effects to the mammalian fauna (Murcia 1995, Stevens \& Husband 1998, Fahrig 2003). Despite not being studied, problems were observed at the edges of the urban fragment, like garbage, fires, movement of people, and pets.

Top predators and species that need greater living ranges are more sensible to the effects of habitat fragmentation, disappearing from smaller fragments (Gilbert et al. 1998, Woodroffe \& Ginsberg 


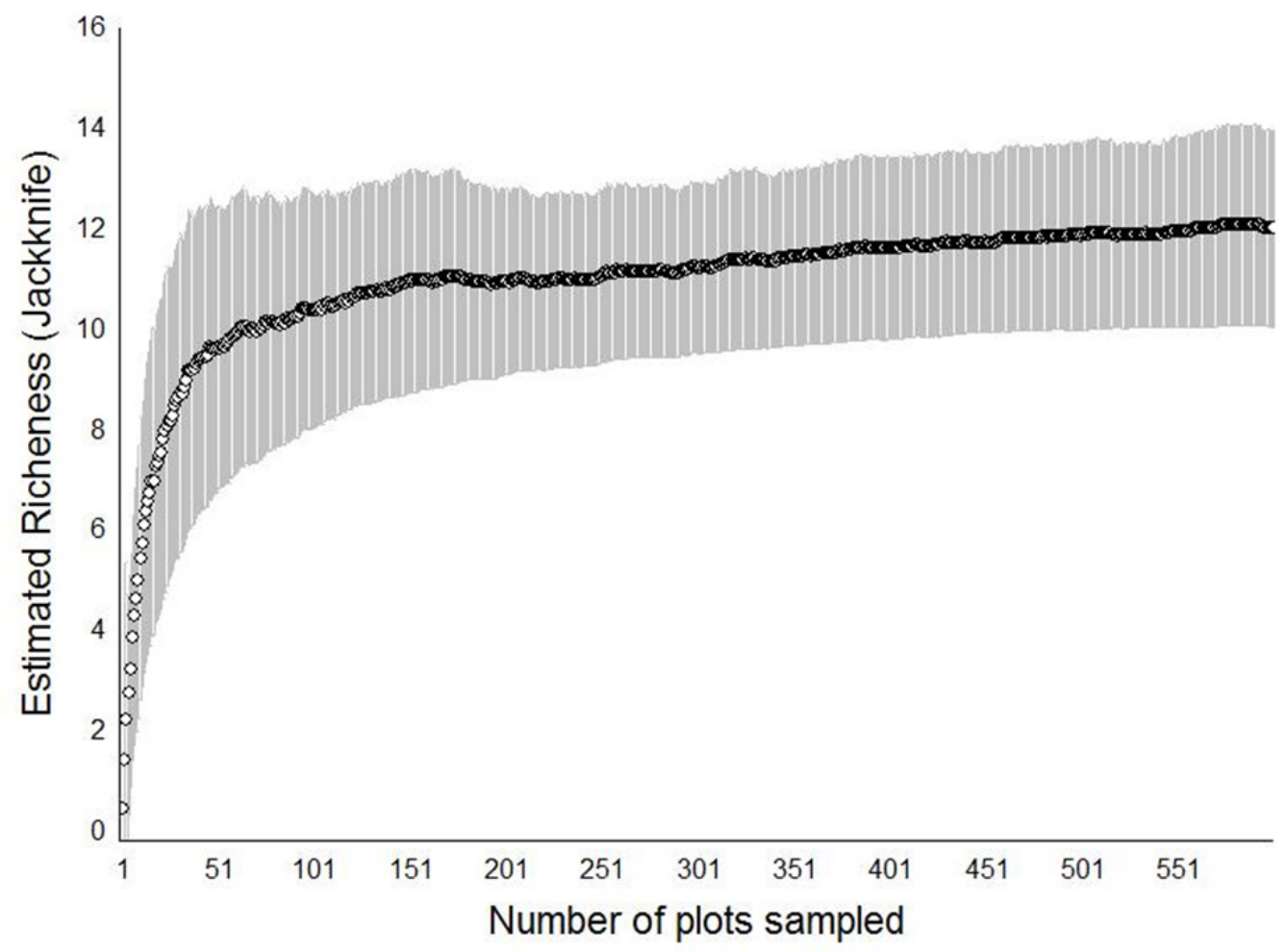

Figure 2. Accumulation curve of large and medium sized mammal species collected between August 2008 and May 2009 from the sampling of an urban forest fragment, in Jataí, Goiás.

1998, Chiarello 1999). However, mesopredators are less affected, like some of the species that were recorded in this remnant (e.g., Nasua nasua, Procyon cancrivorus, Eira barbara). They present great environmental plasticity because they can exist in small fragments, and can move through the anthropic matrix (Michalski \& Peres 2005, Alves-Costa \& Eterovick 2007, Lyra-Jorge et al. 2009). These small fragments, like the studied one, are exposed to the "mesopredator release" phenomena (Crooks \& Soulé 1999), where the extinction of top predators provokes an increase of the number of mesopredators and of the predation of species from lower levels of the food chain, leading them to local extinction.

The presence of people, often related to hunting, is a disturbing factor in fragments and tends to move away and/or locally extinguish the species (Michalski \& Peres 2005, Peres 2001, Chiarello 1999). This is mainly the result of the presence of residences near to the fragments, increasing the likely presence of domestic animals. In this study we recorded the presence of domestic dogs and a feline species that could have been a domestic cat. This is a huge problem for conservation of fauna in small and urban fragments, because the presence of domestic species cause damages, interfere in food chains, and transmit diseases to wild species (Crooks \& Soulé 1999, Crooks 2002, Lacerda et al. 2009).

Through the process of habitat fragmentation, a fragment may gradually lose its species and the the size and diversity of its fauna. This resulting fauna will consist of generalist species (Tabarelli $\&$ Gascon 2005). In this fragment, we have found the species of generalist habits Didelphis albiventris (opossum) frequently recorded. Generalist species are benefited by the processes of habitat fragmentation, because they have greater capability to use different environments, including altered ones (Marvier et al. 2004, Devictor et al. 2008). Because of this, it is also common to find the opossum in residential areas. In addition, species like the opossum and small mammals can increase their abundance in small fragments, due to their generalist habits and to the absence of predators (Fonseca \& Robinson 1990, Chiarello 1999, Michalski \& Peres 2007).

Due to population growth and the advance of cities, forest fragments in the middle of urban centers tend to be common. Despite the size of the impact and the characteristics of the surrounding matrix, the fragment we observed harbors several species of mammals of the Cerrado. However, for an efficient conservation of this fragment, as well as for other fragments in similar conditions, it is necessary to develop ways to improve the fragment and landscape features. The perpetuation of wildlife, the increase of connectivity and of size, the reduction of edge effects, and of the internal impacts arising from the movement of people and pets, are only possible with appropriate management actions.

\section{Acknowledgements}

We thank the Universidade Federal de Goiás and the Secretaria Municipal de Meio Ambiente of Jataí - GO for their logistical support and CNPq for P.V.S Bernardo's scholarship. We also thank Katie Hartman for her proofreading.

\section{References}

ALVES-COSTA, C.P. \& ETEROVICK, P.C. 2007. Seed dispersal services by coatis (Nasua nasua, Procyonidae) and their redundancy with other frugivores in southeastern Brazil. Acta Oecol. 32:77-92. http://dx.doi. org/10.1016/j.actao.2007.03.001

BECKER, M. \& DALPONTE, J.C. 1991. Rastros de mamíferos silvestres brasileiros. Ed. Universidade de Brasília, Brasília. 
BORGES, P.A. \& TOMÁS, W.M. 2004. Guia de rastros e outros vestígios do Pantanal. Embrapa Pantanal, Corumbá.

CARVALHO, F.M.V., DE MARCO JÚNIOR, P. \& FERREIRA, L.G. 2009. The Cerrado into-pieces: Habitat fragmentation as a function of landscape use in the savannas of central Brazil. Biological Conservation. 142:13921403. http://dx.doi.org/10.1016/j.biocon.2009.01.031

CHIARELlO, A. 1999. Effects of fragmentation of the Atlantic forest on mammal communities in south-eastern Brazil. Biol. Conserv. 89:71-82. http://dx.doi.org/10.1016/S0006-3207(98)00130-X

COSTA, L.P., LEITE, Y.L.R., MENDES, S.L. \& DITCHFIELD, A.D. 2005. Conservação de mamíferos no Brasil. Megadiversidade. 1:103-112.

COLWELL, R.K. 2000. EstimateS 7.5. Statistical Estimation of Species Richness and Shared Species from Samples. University of Connecticut. http://viceroy.eeb.uconn.edu/estimates (último acesso em 18/05/2012).

CROOKS, K.R. 2002. Relative sensitivities of mammalian carnivores to habitat fragmentation. Conserv. Biol. 16:488-502. http://dx.doi. org/10.1046/j.1523-1739.2002.00386.x

CROOKS, K.R. \& SOULE, M.E. 1999. Mesopredator release and avifaunal extinctions in a fragmented system. Nature. 400:563-566. http://dx.doi. org $/ 10.1038 / 23028$

DEVICTOR, V., JULLIARD, R. \& JIGUET, F. 2008. Distribution of specialist and generalist species along spatial gradients of habitat disturbance and fragmentation. Oikos. 117:507-514. http://dx.doi.org/10.1111/j.00301299.2008.16215.x

EMMONS, L.H. \& FEER, F. 1997. Neotropical rainforest mammals: a field guide. 2. ed. University of Chicago, Chicago.

FAHRIG, L. 2003. Effects of habitat fragmentation on biodiversity. Annu. Rev. Ecol. Evol. S. 34:487-515. http://dx.doi.org/10.1146/annurev. ecolsys.34.011802.132419

FAHRIG, L. \& MERRIAM. 1994. Conservation of Fragmented Populations. Biodivers. Conserv. 8:50-59.

FERNÁNDEZ-JURICIC, E. 2002. Can human disturbance promote nestedness? A case study with breeding birds in urban habitat fragments. Oecologia. 131:269-278. http://dx.doi.org/10.1007/s00442-002-0883-y

FONSECA, G.A.B. \& ROBINSON, J.G. 1990. Forest size and structure : competitive and predatory effects on small mammal communities. Biol. Conserv. 53:265-294. http://dx.doi.org/10.1016/0006-3207(90)90097-9

GIBSON, L., LEE, T.M., KOH, L.P., BROOK, B.W., GARDNER, T.A., BARLOW, J., PERES, C.A., BRADSHAW, C.J.A., LAURANCE, W.F., LOVEJOY, T.E. \& SODHI, N.S. 2011. Primary forests are irreplaceable for sustaining tropical biodiversity. Nature. 478:378-381. http://dx.doi. org/10.1038/nature 10425

GILBERT, F., GONZALEZ, A. \& EVANS-FREKE, I. 1998. Corridors maintain species richness in the fragmented landscapes of a microecosystem. P. Roy. Soc. B-Biol. Sci. 265:577-582. http://dx.doi.org/10.1098/ rspb.1998.0333

HELTSHE, J.F. \& FORRESTER, N.E. 1983. Estimating species richness using the jackknife procedure. Biometrics. 39:1-11. http://dx.doi. org/10.2307/2530802

KLINK, C.A. \& MACHADO, R.B. 2005. A conservação do Cerrado brasileiro. Megadiversidade. 1:147-155.

LACERDA, A.C.R., TOMAS, W.M. \& MARINHO-FILHO, J. 2009. Domestic dogs as an edge effect in the Brasília National Park, Brazil: interactions with native mammals. Anim. Conserv. 12:477-487. http:// dx.doi.org/10.1111/j.1469-1795.2009.00277.x

LAURANCE, W. 2008. Theory meets reality: How habitat fragmentation research has transcended island biogeographic theory. Biol. Conserv. 141:1731-1744. http://dx.doi.org/10.1016/j.biocon.2008.05.011
LYRA-JORGE, M.C., RIBEIRO, M.C., CIOCHETI, G., TAMBOSI, L.R. \& PIVELLO, V.R. 2009. Influence of multi-scale landscape structure on the occurrence of carnivorous mammals in a human-modified savanna, Brazil. Eur. J. Wildlife Res. 53:359-368.

MACHADO, A.M.B., DRUMMOND, G.M. \& PAGLIA, A.P. 2008. Livro vermelho da fauna brasileira ameaçada de extinção. MMA, Fundação Biodiversitas, Brasília.

MARVIER, M., KAREIVA, P. \& NEUBERT, M.G. 2004. Habitat destruction, fragmentation, and disturbance promote invasion by habitat generalists in a multispecies metapopulation. Risk Anal. 24:869-878. http://dx.doi. org/10.1111/j.0272-4332.2004.00485.x

MICHALSKI, F. \& PERES, C. 2005. Anthropogenic determinants of primate and carnivore local extinctions in a fragmented forest landscape of southern Amazonia. Biol. Conserv. 124:383-396. http://dx.doi. org/10.1016/j.biocon.2005.01.045

MICHALSKI, F. \& PERES, C.A. 2007. Disturbance-mediated mammal persistence and abundance-area relationships in Amazonian forest fragments. Conserv. Biol. 21:1626-40.

MITTERMEIER, R.A., GIL, R.P., HOFFMAN, M., PILGRIM, J., BROOKS, T., MITTERMEIER, C.G., LAMOREUX, J. \& FONSECA, G.A.B. 2005. Hotspots revisited: Earth's biologically richest and most endangered terrestrial ecoregions. 2. ed. University of Chicago Press, Boston.

MIZIARA, F. \& FERREIRA, N.C. 2008. Expansão da fronteira agrícola e evolução da ocupação e uso do espaço no Estado de Goiás: Subsídios á Política Ambiental. In A Encruzilhada Sociambiental: biodiversidade, economia e sustentabilidade no cerrado (L.G. Ferreira Junior, eds.). Editora UFG, Goiânia, p.107-125.

MURCIA, C. 1995. Edge effects in fragmented forests: implications for conservation. Tree. 10:58-62. http://dx.doi.org/10.1016/S01695347(00)88977-6

MYERS, N., MITTERMEIER, R.A., MITTERMEIER, C.G., DA FONSECA, G.A. \& KENT, J. 2000. Biodiversity hotspots for conservation priorities. Nature. 403:853-8. http://dx.doi.org/10.1038/35002501

PERES, C.A. 2001. Synergistic effects of subsistence hunting and habitat fragmentation on amazonian forest vertebrates. Conser. Biol. 15:14901505. http://dx.doi.org/10.1046/j.1523-1739.2001.01089.x

RATTER, J.A., RIBEIRO, J.F. \& BRIDGEWATER, S. 1997. The brazilian Cerrado vegetation and threats to its biodiversity. Ann. BotLondon. 80:223-230. http://dx.doi.org/10.1006/anbo.1997.0469

ROCHA, J.R.R., MARIANO, Z.F., AGUIAR, R.C.P. \& REZENDE, D.F. 2012. Aspectos climáticos e ocorrência de casos de dengue em Jataí-GO. Rev. Geonorte. 2:757-769.

SAMPAIO, R., LIMA, A.P., MAGNUSSON, W. \& PERES, C.A. 2010. Long-term persistence of midsized to large-bodied mammals in Amazonian landscapes under varying contexts of forest cover. Biodivers. Conserv. 19: 2421-2439. http://dx.doi.org/10.1007/s10531-010-9848-3

SANTOS, J. 2006. Estimativas de riqueza em espécies. In Métodos de Estudos em Biologia da Conservação e Manejo da Vida Silvestre (L. Cullen Junior, R. Rudran \& C. Valladares-Padua, eds.). 2. ed. Ed. da UFPR, Curitiba.

STEVENS, S.M. \& HUSBAND, T.P. 1998. The influence of edge on small mammals: evidence from Brazilian Atlantic forest fragments. Biol. Conserv. 85:1-8. http://dx.doi.org/10.1016/S0006-3207(98)00003-2

TABARELLI, M. \& GASCON, C. 2005. Lições da pesquisa sobre fragmentação : aperfeiçoando políticas e diretrizes de manejo para a conservação da biodiversidade. Megadiversidade 1:181-188.

WOODROFFE, R. \& GINSBERG, J.R. 1998. Inside Protected Areas Edge Effects and the Extinction of Populations Inside Protected Areas. Science 280:10-13. http://dx.doi.org/10.1126/science.280.5372.2126 